\title{
The Effects of Visual and Auditory Learning Styles on Students' Learning Outcomes in Historical Social Studies
}

\author{
Zulhamdi Hasian Harahap ${ }^{1}$, Sugiharto ${ }^{2}$, Syarifah ${ }^{3}$ \\ ${ }^{1}$ Student of Master's Degree of Primary Education, Universitas Negeri Medan \\ ${ }^{2,3}$ Lecturers of Master's Degree of Primary Education, Universitas Negeri Medan \\ Jl.WillemIskandarPsr. V Medan Estate, Medan, Indonesia, 20221
}

Corresponding Author: Zulhamdi Hasian Harahap

\begin{abstract}
The aim of this study was to determine the effects of visual and auditory learning styles on students' learning outcomes in historical social studies. The samples were the students of classes VII-2 and VII-3 respectively in MTs. Negeri Binanga. The data collection technique was the learning outcome tests. The instrument for collecting data on students' learning outcomes was in the form of 30 multiple choice tests, and the learning styles consisted of 30 statements. The data analysis technique applied a Two-Way ANOVA with $2 \times 2$ factorial. The results showed that the students' visual and auditory learning styles had the significant effects on students' learning outcomes, where the groups of students who performed a visual learning style $(\overline{\boldsymbol{X}}=75.93)$ was significantly higher than those who performed an auditory learning style ( $\bar{X}=52.90)$ on students' learning outcomes in historical social studies.
\end{abstract}

Keywords: Auditory, Visual, Learning Styles, Learning Outcomes

\section{INTRODUCTION}

In improving the quality of education a teacher does not only have a high level of education but is required to create a creative and innovative learning, because one of the problems in formal education today is the low absorption of students (Meja, 2017).

In fact, the problem of low student learning outcomes also occurs in MTs. NegeriBinanga. The results of interviews with school principals and social studies teachers related to the implementation of the seventh grade social studies learning in MTs. Negeri Binanga obtained some information that in the teaching and learning process students were still passive, there were still many teachers concerned with rote memorizing rather than understanding a material concept, the teacher still dominated the learning activities in the classroom, the students just sat still, listened to the teacher's explanation as well as there was no interactive communication between a teacher and his/her students.

In addition to choosing the right learning model, students' social studies learning outcomes were also influenced by internal factors; learning styles (Prasnig, 2007). The learning models applied by a teacher should be able to develop all student learning styles and not only lead to one learning style. According to Nasution (2008), a learning style is a consistent way in reaching out the stimuli or information, the way of thinking, memorizing, and solving the problems as well. In line with the results of Maiyetri's (2014) study showed that there was a positive and significant influence between visual learning style on students' learning achievement. Learning style is a combination of how it absorbs, and then organizes and processes information (DePorter \& Hernacki, 2013). 
The study from Febrianto, (2014) concluded that there was a positive effect between the suitability of students' learning styles and learning models on their learning activities by $56.6 \%$. Optimal learning outcomes will be obtained if various differences such as habits, interests, and learning styles of students are accommodated by a teacher through the selection of teaching models and teaching materials that are in accordance with student learning styles.

\section{RESEARCH METHOD}

This study was conducted in MTs. Negeri Binanga, The District of Barumun Tengah, PadangLa was Regency from April to May 2018. This type of study was a quasi experimental research. The population was all the seventh grade students of MTs. Negeri Binanga, totaling 155 people. The sample with cluster random sampling, totaling 2 classes out of 5; class VII-2 and VII-3. The instrument of learning style was the VAK Learning Styles' Questionairres. This consisted of 30 statements and only had 3 answers to complete it. The instrument to measure students' learning outcomes employed the 30 multiple choice tests. Each correct answer is given a score of 1 (one), while the wrong answer is given a score of 0 (zero). This test is used to measure the cognitive abilities $\left(\mathrm{C}_{1}-\mathrm{C}_{4}\right)$ of students in the historical social studies. The latticework of data collection instrument of students' learning outcomes was presented in Table 1

Table 1: The Latticework of Learning Outcomes' Tests in Historical Social Studies in the $2^{\text {nd }}$ Semester

\begin{tabular}{|c|c|c|c|c|c|c|}
\hline \multirow[t]{2}{*}{ Basic Competence } & \multirow[t]{2}{*}{ Indicator } & \multicolumn{4}{|c|}{ Rated Aspects } & \multirow[t]{2}{*}{ Total } \\
\hline & & C1 & C2 & $\mathrm{C3}$ & C4 & \\
\hline $\begin{array}{l}\text { Understanding the chronology } \\
\text { of Indonesian society during } \\
\text { the Pre-literary, Hinduism- } \\
\text { Buddhism, and Islam Periods }\end{array}$ & $\begin{array}{l}\text { Describingthe chronology } \\
\text { of Indonesian society } \\
\text { during the Pre-literary, } \\
\text { Hinduism-Buddhism, and } \\
\text { Islam Periods }\end{array}$ & $\begin{array}{l}1,3,4,7, \\
8,9,10, \\
15,19\end{array}$ & $\begin{array}{l}2,5,6,12, \\
16,17,22, \\
23\end{array}$ & $\begin{array}{l}11,18,20 \\
21,24,25\end{array}$ & $\begin{array}{lll}13, & 14, & 26, \\
27, & 28, & 29, \\
30 & & \end{array}$ & \\
\hline \multicolumn{2}{|c|}{ Total } & 9 & 8 & 6 & 7 & 30 \\
\hline
\end{tabular}

\section{RESULTS AND DISCUSSION}

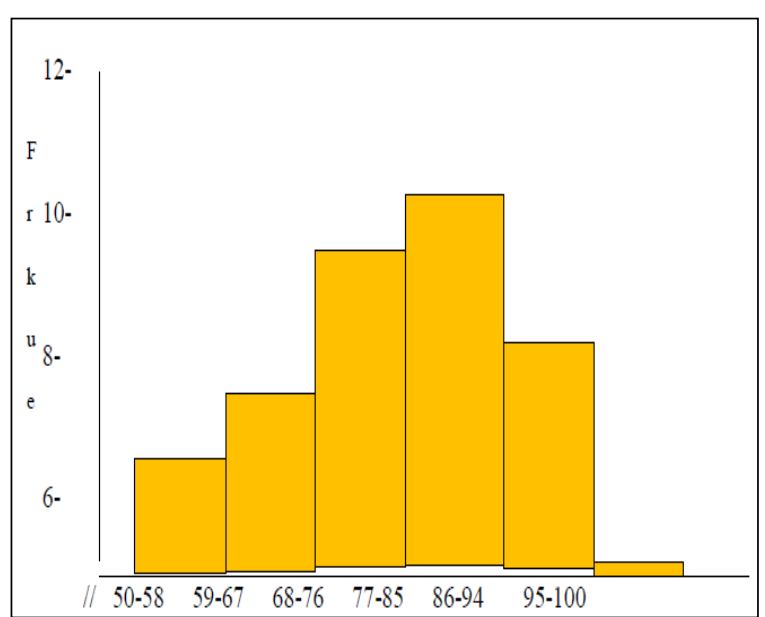

Figure 1: The scores of students' learning outcomes inMTs.NegeriBinanga with a visual learning style by using inquiry and expository learning models

The data of students' learning outcomes in MTs. NegeriBinanga with a visual learning style using inquiry and expository learning models was known that the mean was 75.93 ; mode was 84 ; median was 78 ; variance was 123.72 ; standard deviation was 11.123; maximum score was 94; and minimum score was50. Furthermore, the histogram was presented in Figure 1.

From the data in Figure 1 aforementioned above, the students' learning outcomes can be grouped with a visual learning style was in a good category taught by inquiry and expository learning models divided into 3 categories; in average, in above and in below average ability. Based on the categorization of the data, students who learned with inquiry and expository learning models with visual learning style that were at in average ability of 8 students or $26.66 \%$, in above average of 15 students or $50 \%$ and in below average of 7 students or $23.33 \%$.

The data on students' learning outcomes in MTs.NegeriBinanga inquiry and expository learning models, it was known that the mean was 52.90; mode was 
Zulhamdi Hasian Harahap et.al. The effects of visual and auditory learning styles on students' learning outcomes in historical social studies

36; median was 50; variance was 299.690; standard deviation was 17.312 ; maximum score was 90; and minimum score was 24. Furthermore, the histogram was presented in Figure 2.

From the data in Figure 2 aforementioned above, the students' learning outcomes can be grouped with an auditory learning style was in a good category taught by inquiry and expository learning models divided into 3 categories; in average, in above and in below average ability. Based on the categorization of the data, students who learned with inquiry and expository learning models with auditory learning style that were at in average ability of 8 students or $25.80 \%$, in above average of 13students or $41.91 \%$ and in below average of 10 students or $32.25 \%$.

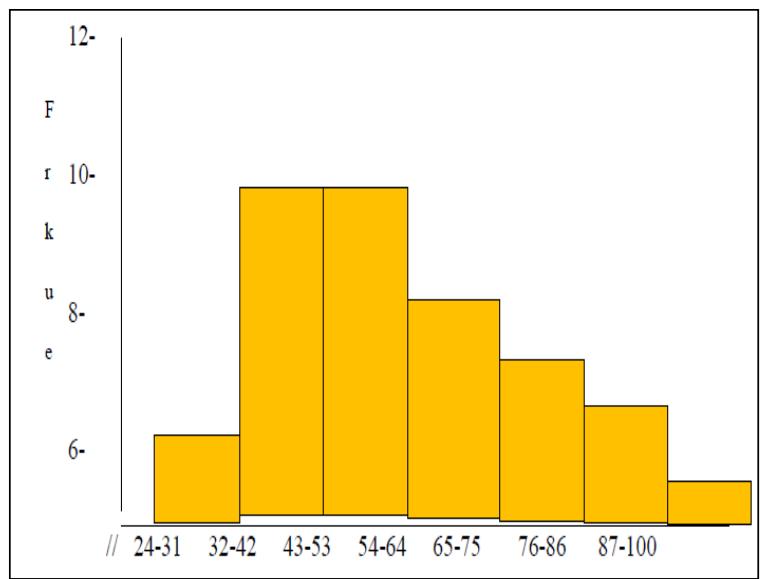

Figure 2: The scores of students learning outcomes in MTs.NegeriBinangawith an auditory learning style by using inquiry and expository learning models

Table 2: The Students' Learning Outcomes Applied by Two-Way ANOVA

\begin{tabular}{|c|c|c|c|c|c|c|c|}
\hline \multirow{2}{*}{\multicolumn{2}{|c|}{ The Data Summary }} & \multicolumn{4}{|c|}{ Learning Models } & \multirow{2}{*}{\multicolumn{2}{|c|}{ Total }} \\
\hline & & \multicolumn{2}{|c|}{ Inquiry } & \multicolumn{2}{|c|}{ Expository } & & \\
\hline \multirow{8}{*}{ Learning Styles } & \multirow{4}{*}{ Visual } & & $=17$ & & $=13$ & \multicolumn{2}{|c|}{$=30$} \\
\hline & & $\sum X$ & $=1392$ & $\sum X$ & $=916$ & $\sum X$ & $=2308$ \\
\hline & & $\bar{X}$ & $=77$ & $\bar{X}$ & $=70.46$ & $\bar{X}$ & $=75.93$ \\
\hline & & $\mathrm{s}$ & $=8.587$ & $\mathrm{~s}$ & $=10.96$ & $\mathrm{~s}$ & $=9.77$ \\
\hline & & & $=13$ & & $=18$ & & $=31$ \\
\hline & Auditory & $\sum x$ & $=918$ & $\sum X$ & $=750$ & $\sum X$ & $=1668$ \\
\hline & & $\bar{X}$ & $=69.08$ & $\bar{X}$ & $=41.67$ & $\bar{X}$ & $=52.90$ \\
\hline & & & $=9.987$ & & $=8.657$ & $\mathrm{~s}$ & $=9.322$ \\
\hline \multirow{4}{*}{\multicolumn{2}{|c|}{ Total }} & & $=30$ & & $=31$ & & \\
\hline & & $\sum X$ & $=2310$ & $\sum X$ & $=1666$ & & \\
\hline & & $\bar{X}$ & $=73.04$ & $\bar{X}$ & $=56.06$ & & \\
\hline & & $\mathrm{s}$ & $=9.287$ & $\mathrm{~s}$ & $=9.809$ & & \\
\hline
\end{tabular}

Table 3: The Data Summary of Two-Way ANOVA

\begin{tabular}{|l|c|c|c|c|c|c|}
\hline Sources of Variation & $\mathbf{d k}$ & $\mathbf{J k}$ & $\mathbf{R j k}$ & $\mathbf{F}_{\text {value }}$ & $\mathbf{F}_{\text {table }}(\mathbf{0 , 0 5})$ & Info \\
\hline Learning Models & 1 & 8154.31 & 8154.31 & 68.37 & 4.140 & Significant \\
\hline Learning Styles & 1 & 6977.1 & 6977.1 & 60.76 & 4.140 & Significant \\
\cline { 1 - 3 } Interaction & 1 & 309.53 & 309.53 & 58.50 & 4.140 & Significant \\
\cline { 1 - 4 } Error & 57 & 6798.07 & 119.26 & & & \\
\cline { 1 - 4 } \multicolumn{1}{|c|}{ Total } & $\mathbf{6 0}$ & $\mathbf{2 2 2 3 9 . 0 1}$ & - & & & \\
\cline { 1 - 3 }
\end{tabular}

The results of the variance analysis calculation in testing the hypothesis could be presented in Table 3 .

The hypothetical testing of students' learning outcomes who performed the visual and auditory learning styles can be presented down below.

$\mathrm{H}_{0}: \mu \mathrm{B}_{2} \leq \mu \mathrm{B}_{1}$

$\mathrm{H}_{\mathrm{a}}: \mu \mathrm{B}_{2}>\mu \mathrm{B}_{1}$

Based on the calculation of the TwoWay ANOVA with $2 \times 2$ factorial obtained the $F_{\text {value }}$ was 60.76 , while the value of $F_{\text {table }}$ was 4.14 for $\mathrm{dk}(1.57)$ in a significance level of 0.05 . It turns out that the value of $\mathrm{F}_{\text {value }}$ was 60.76 higher than $F_{\text {table }}$ was 4.14 . It means that the hypothetical testing rejected the null hypothesis and accepted the alternative hypothesis. Thus it could be concluded that the students' learning outcomes who performed a visual learning style were higher than those who performed an auditory learning style. This could also be seen from the average learning outcomes of students who performed a visual learning style $(\bar{X}=75.93)$ was significantly higher 
than those who performed an auditory learning style ( $\bar{X}=52.90)$ as well.

In learning processes, students have advantages and disadvantages in absorbing the lessons given and each student also possess a different learning style that dominates its characteristics. Uno (2008) states that not every single person has the same learning style in absorbing lessons, including if they go to the same school or even sit in the same class. Gunawan\&Adi (2007) state that learning styles are the preferred way of thinking, processing and understanding information. For example, if students want to learn about plants, do students prefer to watch videos about plants, listen to lectures, read books or work directly on plantations or visit botanical gardens.

Students will learn with all their potentials, for example those who have a dominant auditory learning style by listening to the material presented by the teacher. Likewise, students who have a predominantly visual learning style will learn by seeing what is in front of them in the form of visuals, pictures, colors, diagrams, and maps. Therefore it is rare to find students who only use one learning style, usually a combination of several learning styles, but it is argued that individuals have all learning styles; only usually one learning style dominates. In accordance with the research results of Jagantara, et al. (2014) concluded that there are significant differences in learning outcomes between students who have auditory learning styles and visual learning styles.

A visual learning style understands the information from what is seen. It requires concrete evidence that must be presented in order to understand the problem. The auditory learning style in dealing with problems with procedures, debating problems, solving solutions, speaking at moderate speed, eager to talking in class, promoting communication, remembering well and memorizing words and ideas that have been spoken, responding better when listening than reading. This difference in students' learning styles certainly affected the success of students in learning the subject matter.

Furthermore, it can be concluded that the students' learning outcomes who performed a visual learning style were significantly higher than those who performed an auditory learning style. The results of this study were in accordance with the results of research by Purwaningsih, et al. (2011) that the suitability of learning styles helps students to learn effectively in the right way, mean while the learning model is only one way to achieve the optimal learning outcomes by a teacher.

\section{CONCLUSION}

Students' visual and auditory learning styles had the effects on students' learning outcomes, where groups of students who performed a visual learning style obtained the higher learning outcomes than those who performed an auditory learning style

\section{REFERENCES}

1. Deporter, B., Hernacki, M. 2013.Quantum Teaching. Bandung: Kaifa.

2. Febrianto, A. 2014. The Effects of Classroom Management Skills and Students' Learning Styles on Learning Activeness of Class XI in High School Economic Development Learning Materials. 2 (3): 1-8.

3. Gunawan., Adi, W. 2007. Genius Learning Strategy. Jakarta: GramediaPustakaUtama.

4. Jagantara, I., Adnyana, P., Widiyanti, N. 2014. The effects of Project-based Learning Models on Learning Outcomes in Terms of Students' Learning Styles. Journal of Ganesha University of Education Graduate Program, 11(4): 1-13.

5. Maiyetri, R. 2014. The Influence of Visual and Auditory Learning Styles, and Critical Thinking Skills on Students' Achievements of Class XII Social Sciences in Economics Subjects in SMA Negeri 8 Padang. Journal of Economic and Economic Education. 2(2): 100-109.

6. Meja, M. 2017. Application of Inquiry Learning Model to Improve Students' 
Zulhamdi Hasian Harahap et.al. The effects of visual and auditory learning styles on students' learning outcomes in historical social studies

Social Studies Learning Outcomes of Class V. Journal of Primary School Teacher Education Edition 7, 6th Year (706-715).

7. Nasution, A. 2008.Various Approaches in Teaching and Learning Process. Jakarta: BumiAksara.

8. Prasnig, B. 2007.The Power of Learning Style. Bandung: Kaifa.

9. Purwaningsih, D., Harlita.,Sugiharto, B. 2011. The Effect of Using Active Knowledge Sharing Learning Strategies on
Learning Outcomes in terms of Learning Style of Class X Students of SMA Negeri 5 Surakarta in 2011/2012. Journal of Education, 3(3): 91-102.

How to cite this article: Zulhamdi Hasian Harahap, Sugiharto, Syarifah. The effects of visual and auditory learning styles on students' learning outcomes in historical social studies. International Journal of Research and Review. 2021; 8(1): 72-76. 